\title{
BRIEF REVIEW OF RUSSIAN-LANGUAGE LITERATURE ON THE GYRFALCON (FALCO RUSTICOLUS)
}

\author{
JeVgeni Shergalin \\ International Wildlife Consultants Ltd., P.O. Box 19, Carmarthen SA33 5YL, Wales, UK. \\ E-mail: jevgeni@falcons.co.uk
}

\begin{abstract}
About 50\% of the world range of the Gyrfalcon (Falco rusticolus) is in Russia, with the highest density in the southern Yamal, and the largest numbers located in Kamchatka. The main source of information on Russian Gyrfalcons is the monograph "Gyrfalcons" by Dementiev, published in 1951 and later translated into German and English. Analysis of Russian literature on the Gyrfalcon for the second half of the $20^{\text {th }}$ Century was undertaken by E. Potapov and R. Sale in their joint monograph “The Gyrfalcon," published by Poyser in 2005. In the mid-1990s, I prepared for the company of Dr. Nick Fox an annotated bibliography in English on the Gyrfalcon in the territory of the ex-USSR, available free upon request. The list includes 490 entries on 64 pages, predominantly in Russian, covering the period 1656-1995. The majority of entries include episodic observations during avifauna investigations of vast areas, and only 25 articles and species accounts are dedicated exclusively to the Gyrfalcon. Following the collapse of the USSR, visits to arctic regions declined, poaching developed, and long-term studies on the Gyrfalcon became almost impossible due to a shortage of funds. However, a number of important publications have appeared and are available, along with other information, on the Internet in both Russian and English. Most of the literature deals with breeding biology, descriptions of breeding sites, and other observations, whereas other aspects of biology and ecology are insufficiently studied. Absence of work on post-breeding movements, winter ecology and taxonomy is apparent. Received $28 \mathrm{Feb}$ ruary 2011, accepted 28 June 2011.
\end{abstract}

Shergatin, J. 2011. Brief review of Russian-language literature on the Gyrfalcon (Falco rusticolus). Pages 239-242 in R. T. Watson, T. J. Cade, M. Fuller, G. Hunt, and E. Potapov (Eds.). Gyrfalcons and Ptarmigan in a Changing World, Volume II. The Peregrine Fund, Boise, Idaho, USA. http://dx.doi.org/10.4080/gpcw.2011.0301

Keywords: Gyrfalcon, Russia, Arctic, smuggling, literature, journals.

RUSSIA ENCOMPASSES about $50 \%$ of the world's Gyrfalcon (Falco rusticolus) range. The main source of information on the Gyrfalcon in Russia was the monograph "Gyrfalcons" by Professor Georgiy P. Dementiev (1898-1969) published in 1951 and later translated into German and English (Demen- tiev 1951, Dementiev 1960). Analysis of Russian literature on the Gyrfalcon for the second half of the $20^{\text {th }}$ Century was undertaken by Dr. Eugene Potapov and Richard Sale in their joint monograph "The Gyrfalcon" published by Poyser in 2005. 
In the mid-1990's, I prepared for the company of Dr. Nick Fox an annotated bibliography in English on the Gyrfalcon from the territory of the ex-USSR, available free upon request. The list included 490 entries on 64 pages predominantly in Russian, covering the period 16561995. The majority of entries include episodic observations during avifauna investigations of vast areas, and only 25 articles and species accounts were dedicated exclusively to the Gyrfalcon. Following the collapse of the USSR, visits to Gyrfalcon breeding areas declined, poaching came about, and long term studies on the Gyrfalcon were almost impossible to manage due to a shortage of funds. However a small number of important articles have appeared and are listed as follows: The Gyrfalcon Falco rusticolus in the Lake Baikal Region by Ryabtsev (1997); Ecological bases and resettlement ways of the Gyrfalcon Falco rusticolus in the tundra of the European part of Russia by Morozov (2000); Gyrfalcon in Yakutia: distribution, breeding ranges, feeding peculiarities by Labutin and Ellis (2006); Status and monitoring of the Peregrine and Gyrfalcon in the Kola Peninsula, Russia by Ganusevich (2006); Observations of the Gyrfalcon in Bulgaria by Nankinov (2007); Five fledglings of the Gyrfalcon on the Yamal Peninsula by Mechnikova and Kudryavtsev (2007); Materials on the Gyrfalcon population status in Kamchatka by Lobkov et al. (2007); and Gyrfalcon and Goshawk food in Lapland by Gilyazov et al. (2008). I translated the main articles on the Gyrfalcon from Russian into English for Dr. Tom Cade during 2000-2005, and they are available on request.

Additional data on the Gyrfalcon may be found in the Red Data Books of different administrative units of Russia, for example, the Murmansk Region (2003), Kamchatka (2006), Nenets District (2006), Magadan Region (Kolyma) (2008), Chukotka (2008), and others. A general review in the entire Red Data Book of the Russian Federation was produced by Dr. Sergei A. Ganusevich (2001), the hero of the recent documentary film "Ponoi Depres- sion" about his work with raptors at the Ponoi depression at the Centre of the Kola Peninsula (http://ruslapland.livejournal.com/17981.html).

The quality of data in species accounts of the Gyrfalcon is quite variable. Several short communications are published in the express issues of the Russian Journal of Ornithology (only electronic versions of them are available at the Russian electronic library at www.elibrary.ru). This journal often reprints old articles, such as work by the late Professor Alexei V. Mikheev (1907-1999) (Mikheev 2002), originally published in 1941. Meteorological conditions and the general situation for Arctic breeding birds are regularly reflected on the pages of the electronic newsletter "Arctic Birds" (http:// www.arcticbirds.net/). Some articles and short communications, especially on smuggling and poaching of the Gyrfalcon in Russia, are described in the Newsletter of the MiddleEastern Falcon Research Group "Falco," completely in English (http://www.mefrg.org/ falco.asp), and in "Raptor Conservation," which appears in Russian and English (http://www.sibecocenter.ru/RC.htm). Over several years, four new zoological journals were launched: the Altai Zoological Journal, the Baikalian Zoological Journal, the Amurian Zoological Journal, and the Far-Eastern Ornithological Journal (http://birdland.ru/). The Gyrfalcon stock held in captivity is reflected in the review tables published by EARAZA and the Moscow Zoo annually in the series "Birds of Prey and Owls in Zoos and Breeding Centers," in Russian and English (http://www.moscowzoo.ru/get.asp?id=C78).

Good articles on breeding biology are known from the Kola Peninsula, the Bolshezemelskaya tundra, the southern part of the Yamal Peninsula, Taimyr, Kolyma, and Kamchatka. Information on breeding biology and reports of episodic observations with descriptions of breeding sites dominate the literature, while other aspects of biology and ecology are insufficiently studied, but there is largely an absence of work on post-breeding movements, 
winter ecology, and taxonomy. Poaching pressure was investigated only in Kamchatka (Lobkov et al. 2007). Analysis of fragmentary data on poaching (mainly seizures of smuggled birds at airports) on the basis of media sources is described in a series of publications by Nikolenko (2007, 2009), Nikolenko and Karyakin (2007), and Lyapustin (2008). Several works are devoted to the problem of Gyrfalcon mortality in traps set for Arctic Foxes (Vulpes lagopus) (Ellis 1993, Glenn 1993, Gavrilov 2007). In 1987, the Lithuanian team of P. Abukiavichius, G. Grazhuliavichius, and A. Baronas made a 19-minute documentary film "In Search of the White Gyrfalcon," made at the Kolyma River mouth in the Russian Far East (http://www.getmovies.ru/details.aspx ?item $=94632$ ).

\section{Literature Cited}

Dementiev, G. P. 1951. Sokola krecheti. Izdatel'stvo Moskovskovo Obschectva Ispitatelyei, Prirodi, Moskva, Russia (in Russian).

Dementiev, G. P. 1960. Der Gerfalke (Falco gyrfalco L. = Falco rusticolus L.). Die Neue Brehm-Bücherei, no. 264. A. Ziemsen Verlag, Wittenberg, Germany (in German).

Dementiev, G. P. 1960. Der Gerfalke (Falco gyrfalco L. = Falco rusticolus L.). A. Ziemsen Verlag, Wittenberg, Germany. (Canadian Wildlife Service Translation TR-GR-28).

ELLIS, D. 1993. Predvaritelnoe soobshchenie o vysokoi smertnosti krecheta i beloi sovy v Severnoi Sibiri [Preliminary report of extensive Gyrfalcon and Snowy Owl mortality in Northern Siberia] Informacionnyi vestnik po khishchnym pticam i sovam Rossii. Raptor-Link 1(2):3-4 (in English and Russian).

GANusevich, S. A. 1992. Results of long-term studies of raptor populations in the Kola Peninsula (NW Russia). Pages 7-8 in Raptor Conservation Today. Proceedings of the IV World Conference on Birds of Prey and
Owls, 10-17 May 1992. World Working Group on Birds of Prey, Berlin, Germany. Ganusevich, S. A. 2001. Krechet [The Gyrfalcon]. Pages 454-455 in V. I. DanilovDanilyan (Ed.). Krasnaya kniga Rossijskoi Federatsii. Zhivotnye [The Red Data Book of the Russian Federation. Animals]. ASTAstrel, Moscow, Russia (in Russian).

GANUSEVICH, S. A. 2006. Status and monitoring of the Peregrine and Gyrfalcon in the Kola Peninsula, Russia. Pages 30-36 in P. Koskimies and N. V. Lapshin (Eds.). Status of Raptor Populations in Eastern Fennoscandia. Proceedings of the Workshop, Kostomuksha, Karelia, Russia, 8-10 November 2005.

GAVRILOv, A. A. 2007. O gibeli khishchnykh ptic v kapkanakh na Taimyre [On the birds of prey loss in traps in Taimyr]. The Russian Journal of Ornithology 16:(381): 1357-1358. Reprint of article, originally published in 1991 (in Russian).

Gilyazov, A. S., R. TORnBERG, AND T. HietAJARVI. 2008. Pitanie krecheta i yastrebateterevyatnika $\mathrm{v}$ Laplandii $\mathrm{v}$ raione sovmestnogo obitaniya [The Gyrfalcon and Goshawk food in Lapland in the region of joint occurrence]. Pages 82-85 in Izuchenie i okhrana khishchnyh ptic Severnoi Evrazii [Research and Conservation of Raptors in Northern Eurasia]. Materials of the 5th Conference on Raptors of Northern Eurasia, Ivanovo, 4-7 February 2008. Ivanovo University Press, Ivanovo, Russia (in Russian).

GLENN, T. 1993. Neskol'ko sovetov, kak predotvratit gibel sov v Rossiskoi Arktike [Advice on how to avoid Snowy Owl loss in the Russian Arctic]. Informacionni vestnik po khishchnym pticam i sovam Rossii. Raptor Link 1(2):4 (in English and Russian).

KaLYaKin, V. N. 1992. On the ecology of the Gyrfalcon Falco rusticolus in South Yamal Peninsula (Russia). Page 57 in Raptor Conservation Today. Proceedings of the IV World Conference on Birds of Prey and 
Owls, 10-17 May 1992. World Working Group on Birds of Prey, Berlin, Germany.

Labutin, Yu. V., and D. H. Ellis. 2006. Krechet (Falco rusticolus) v Yakutii: rasprostranenie, gnezdovye oblasti, osobennosti pitaniya [Gyrfalcon in Yakutia: Distribution, breeding ranges, feeding peculiarities]. Zoologicheskiy Zhurnal. vol. 85, 11:1354-1362 (in Russian with English summary).

Lobkov, E. G., N. Yu Gerasimov, and A. V. Gorovenko. 2007. Materialy po sostoyaniyu populyatsii krecheta na Kamchatke [Materials on the Gyrfalcon population status in Kamchatka]. Ornitologiya (Moscow) 34(1):5-35 (in Russian with English summary).

LyAPUSTIN, S. N. 2008. Kontrabanda redkikh khishchnykh ptic na Dal'nem Vostokeugroza ikh sushchestvovaniyu [Smuggling of rare birds of prey in the Russian Far East-threat to their existence]. Raptors Conservation 14:32-38 (in Russian with English summary).

Mechnikova, S. A., AND N. V. KudRYAVtSEV. 2007. Pyat' sletkov v vyvodke krecheta na Yamale, Rossiya [Five fledglings of the Gyrfalcon on the Yamal Peninsula, Russia]. Raptors Conservation 10:61 (in Russian).

Mechnikova, S. A., M. S. Romanov, V. N. KaLYAKIN, AND N. V. KudRYAVTSEV. 2010. Krechet na Yamale: Dinamika velichiny vyvodka i razmerov gnezd $\mathrm{v}$ period 1973-2008 [The Gyrfalcon in Yamal: Dynamics of brood size and nest size during the period 1973-2008]. Ekologiya 41(3):219-226 (in Russian with English summary).

MikheEv, A. V. 2002. Nekotorye sevedeniya o krechete Falco gyrfalco v Timanskoi tundre [Some data on the Gyrfalcon Falco gyrfalco in Timan tundra]. Russian Journal of Ornithology, Express issue. 199:905-907 (in Russian). Reprint of 1941.

Morozov, V. V. 1991. Sapsan i krechet na krainem Severo-Vostoke Evropy [The Peregrine Falcon and Gyrfalcon in the extreme North-East of Europe]. Byulletin
Moskovskogo Obschestva Ispitatelyei Prirody Otdel Biologischeskii [Bulletin of Moscow Naturalists' Society, Department of Biology]. 96(1):57-65 (in Russian with English summary).

Morozov, V. V. 2000. Ekologicheskie osnovy i puti rasseleniya krecheta Falco rusticolus v tundrah Evropeiskoi chasti Rossii [Ecological basis and resettlement ways of the Gyrfalcon Falco rusticolus in the tundra of the European part of Russia]. Russian Journal of Ornithology. Express-issue 95:3-11 (in Russian).

NANKINOv, D. N. 2007. Nablyudenie krecheta Falco rusticolus $\mathrm{v}$ Bolgarii [Observations of the Gyrfalcon Falco rusticolus in Bulgaria]. Russian Journal of Ornithology vol. 16. Express issue 393:1725-1727 (in Russian). NiKOLENKO, E. G. 2007. Rezul'taty proekta po izucheniyu nelegalnogo sokolinogo biznesa v Altae-Sayanskom regione v 2000-2006 [Results of the project on illegal falcon trade in Altai-Sayany region in 2000-2006]. Raptors Conservation 8:22-41 (in Russian with English summary).

Nikolenko, E. G. 2009. Rynok khishchnykh ptic v Rossii-razvitie prodoljaetsya [Trade in raptors in Russia-growth continues]. Raptors Conservation 15:15-21 (in Russian with English summary).

NiKOlenKo, E. G., AND I. V. KARYAKIN. 2007. Sokolinyi biznes na rubeje vekov: mify i fakty [Trade of falcons at the edge of centuries: Myths and facts]. Raptors Conservation 8:12-21 (in Russian with English summary).

Potapov, E. R., AND R. SAle. 2005. The Gyrfalcon. A. \& C. Black, London, UK.

RyABTSEV, V. V. 1997. Krechet Falco rusticolus v Pribaikalie [The Gyrfalcon Falco rusticolus in the Lake Baikal Region]. Russian Journal of Ornithology, Express issue 27: 3-5 (in Russian).

Sorokin, A. G. 2009. Kondo-alymskaya ornitologicheskaya anomaliya, Rossiya [Kondo-Alym ornithological anomaly, Russia]. Raptors Conservation 15:90-97 (in Russian with English summary). 